\title{
Efficacy of Whole Blood Reconstituted (WBR) in Exchange Transfusion (ET) in Hemolytic Disease of New Born (HDN) -A Study of 110 Cases
}

\author{
Dharmesh Chandra Sharma $^{1 *}$, Sunita Rai ${ }^{1}$, Sudha Iyengar ${ }^{1}$, Bharat Jain ${ }^{1}$, Satya Sao ${ }^{2}$, Ajay Gaur ${ }^{1}$, \\ Rahul Sapra ${ }^{3}$ \\ ${ }^{1}$ Department of Pathology, Gajra Raja Medical College, Gwalior, India; ${ }^{2}$ Emergency Blood Bank, Gwalior, India; ${ }^{3}$ Kilkari Nursing \\ Home, Gwalior, India. \\ Email: *dr_dharmesh_sharma@yahoo.com
}

Received December $11^{\text {th }}, 2012$; revised January $25^{\text {th }}, 2013$; accepted February $8^{\text {th }}, 2013$

\begin{abstract}
Aim: This study was aimed to review and establish the practice of exchange transfusion (ET) with whole blood reconstituted (WBR) in hemolytic disease of newborn (HDN). Objectives: To observe fall in indirect serum bilirubin, correction of anemia and comparison with related studies. Background: Hemolytic disease of the Newborn is characterized by presence of IgG antibodies in maternal circulation, which causes hemolysis in the fetus by crossing the placenta and sensitizing red cells for destruction by macrophages in the fetal spleen with consequent hyperbilirubinemia. Exchange transfusion with or without phototherapy is the method of choice for treating the newborn with on going hemolysis Methods/Materials: Sample size consisted of 110 neonates in whom 119 exchange transfusions were carried out with WBR. WBR was prepared by suspending O Rhesus-D (RhD) positive/negative cells (compatible with neonate's/ mother's serum) in AB plasma. Double volume exchange transfusion(s) were carried out through umbilical vein by push-pull technique. Results: Out of 110 cases, 61 (55.5\%) were of RhD HDN whereas ABO and other group HDN cases were $30(27.3 \%)$ and 19 (17.3\%) respectively. An average post-ET fall in indirect serum bilirubin by 54.6\% and correction of anemia by $3.7 \mathrm{gm} / \mathrm{dl}$ were reported in the study. Conclusion: An average post-ET fall in indirect serum bilirubin and correction of anemia was found to be more significant when compared to other studies. Hence we recommend exchange transfusion in HDN with WBR to obtain reasonable fall in indirect serum bilirubin and high average rate of correction of anemia.
\end{abstract}

Keywords: Whole Blood Reconstituted (WBR); Hemolytic Disease of Newborn (HDN); Exchange Transfusion (ET); Hyperbilirubinemia; Anemia Correction

\section{Introduction}

Hemolytic disease of the Newborn (HDN) is characterized by presence of IgG antibodies in maternal circulation, which causes hemolysis in the fetus by crossing the placenta and sensitizing red cells for destruction by macrophages in the fetal spleen with consequent hyperbilirubinemia [1]. Early detection and treatment of neonatal hyperbilirubinemia is important in prevention of bilirubin-induced encephalopathy [2]. It is classified as RhD HDN, ABO HDN and HDN due to other blood group antibodies (non- $\mathrm{ABO}$, non-RhD) according to the specificity of causative IgG antibodies. RhD incompatibility is still the most common cause of HDN, although other RBC incompatibilities are increasing in incidence

*Corresponding author.
[3]. Exchange transfusion with or without phototherapy is the method of choice for treating the newborn with on going hemolysis. Exchange transfusion (ET) removes indirect serum bilirubin, circulating mother's antibodies and antibody-coated neonate's red blood cells (RBCs) from the circulation and provides RBCs compatible with neonate's serum and albumin with new bilirubin binding sites [4]. For exchange transfusion in HDN, whole blood either compatible with neonates' serum or mother's serum is commonly used [5]. Present study was undertaken by whole blood reconstituted for exchange transfusion in all three groups (present study includes only the immunogenic causes of HDN), i.e.; 1) RhD HDN group; 2) ABO HDN group; and 3) Other group HDN. The objecttive of this study is to establish the role of practicing whole blood reconstituted (WBR) for exchange transfusion (ET) in hemolytic disease of newborn (HDN). 


\section{Material and Methods}

This study was carried out in The Blood Bank, Department of Pathology, G.R. Medical College and Emergency Blood Bank, Gwalior, India from May 2005 to December 2007. Both centers are licensed and fully equipped for component preparation with the facility of deep fridge centrifuge, laminar flow, plasma extractor, dielectric tube sealer, deep fridge of $-40^{\circ} \mathrm{C}$ and $-70^{\circ} \mathrm{C}$, sterilized connecting device, cryo water bath etc. WBR was supplied to HDN cases hospitalized in Newborn Care Units of various hospitals. All the cases of HDN were diagnosed by testing cord blood/neonate blood for $\mathrm{ABO}$ grouping and Rh typing, Direct Coomb's test (DCT), Indirect Coomb's test (ICT), total and indirect serum bilirubin along with mother's sample for $A B O$ grouping, RhD typing and ICT. Based on these above tests cases were divided into following three groups:

1) RhD HDN group-Where mother was RhD negative and neonate was RhD positive and ICT \& DCT in neonates and ICT in mother were positive.

2) ABO HDN group-Where mother was of $O$ group and neonate was $A_{1} / A_{2} / B / c i s s-A B$ group and IgG antibodies of $\mathrm{ABO}$ group were detected in neonates.

3) Other Blood group HDN (Non-ABO, Non-RhD) where DCT and ICT in neonates and ICT in mother were positive by using polyspecific coomb's serum.

Other laboratory investigations carried out are hemoglobin $(\mathrm{Hb})$, hematocrit, peripheral smear, reticulocyte count in neonates and $\mathrm{ABO}$ and $\mathrm{RhD}$ status of father if not done during pregnancy.

All blood products were acquired from relative/voluntary donors and underwent routine screening for infectious agents as per guidelines of Food \& Drug Administration Government of India. The whole blood reconstituted was prepared in Blood Bank by standard method of preparation of component i.e. centrifugation and separation method by separating and mixing of Fresh Plasma (FP)/Fresh Frozen Plasma (FFP) and Packed RBC (PC)/ Leuco-reduced RBCs (LC)/Saline Wash RBC (SC) [6]. The fresh plasma is liquid portion of anticoagulated blood remaining after separation from the cellular component, fresh frozen plasma is the plasma separated from whole blood frozen within 6 hours of collection and stored at $-20^{\circ} \mathrm{C}$ and below, leuco-reduced RBCs prepared by discarding the buffy coat from the packed RBC and saline wash RBCs are obtained by washing the packed RBCs with isotonic normal saline thrice. Irradiated RBCs (Leuco-depleted RBCs) were not used in this study due to limited facilities. Freshly collected, whole blood (within 6 hours of collection) was used for preparation of PC/LC/SC. The volume of whole blood reconstituted (WBR) for double volume exchange transfusion was calculated as twice the blood volume of neonate $(2 \times$
$85 \mathrm{ml} / \mathrm{kg}=170 \mathrm{ml} / \mathrm{kg}$ ) [7] and volume of PC/LC/SC and FFP/FP was calculated as [8].

Total Volume of PC/LC/SC

$=\frac{\text { Total Volume of WBR } \times \text { Desired HCT of WBR }}{\text { HCT }}$

$$
\mathrm{HCT} \text { of PC/LC/SC }
$$

\section{Total volume of FFP/FP = Total Volume of WBR -} Volume of PC/LC/SC

The hematocrit of the WBR is adjusted to the range of $45 \%$ to $60 \%$ depending on the desired end result. Higher range is being used for correction of severe anemia [9].

WBR was prepared by suspending $\mathrm{O} \mathrm{RhD}$ positive/ negative cells (PC/LC/SC) in AB plasma (FP/FFP) and was supplied for ET. In RhD HDN; O RhD negative cells [10], in ABO HDN; O RhD positive/negative cells (depending on the $\mathrm{RhD}$ status of neonate), while in other group HDN (non-ABO and non-RhD); ICT cross matched $\mathrm{O}$ positive/negative Cells (depending on the RhD status of neonates) were used. Under all aseptic precautions exchange transfusion(s) were carried out through the umbilical vein under antibiotic coverage in pediatric department by push-pull technique [11,12]. Blood exchange in each cycle varied with weight, maturity and general condition of neonates. In the present study the volume of the WBR used for exchange transfusion was calculated as $160 \mathrm{ml} / \mathrm{kg}$ in term neonates and $180 \mathrm{ml} / \mathrm{kg}$ in preterm neonates [12] that was $170 \pm 10 \mathrm{ml} / \mathrm{kg}$. Single and double surface phototherapy was given to all the patients before and after exchange transfusion. Post-ET blood sample was collected for estimation of hemoglobin, hematocrit, and indirect serum bilirubin and to perform ICT \& DCT. Post-ET fall in indirect serum bilirubin and correction of anemia was observed in all cases.

\section{Subjects Studied}

110 newborns, those diagnosed as Hemolytic disease of newborn (HDN) were subjected for study. Exchange transfusion (ET) with whole blood reconstituted (WBR) and double surface phototherapy were given.

\section{Results}

Present study was conducted on 110 cases of HDN in whom 119 exchange transfusions were performed by whole blood reconstituted (WBR). Out of these 110 cases, in 101 cases (91.8\%) ET was performed once while in 9 cases $(8.2 \%)$ where pre-ET indirect serum bilirubin was above $40 \mathrm{mg} / \mathrm{dl}$ ET was performed twice. Out of these nine cases, 8 cases belonged to RhD HDN (88.8\%) and one case was of other blood group HDN (11.2\%). In this study average age of neonate was 4 days (range 2 - 9 days), average weight of neonate was 2160 gm (range 1100 - 3100 gm), average volume of WBR used was 342 
$\mathrm{ml}$ (range 180 - $480 \mathrm{ml}$ ) (Table 1). Average pre-ET indirect serum bilirubin was $27.9 \mathrm{mg} / \mathrm{dl}$ (range 16.2 - 45 $\mathrm{mg} / \mathrm{dl}$ ) and average pre-ET $\mathrm{Hb}$ was $12.5 \mathrm{gm} / \mathrm{dl}$ (range 10.2 - $13.9 \mathrm{gm} / \mathrm{dl}$ ). Average post-ET serum bilirubin was $12.7 \mathrm{mg} / \mathrm{dl}$ (range 7.9 - $23.2 \mathrm{gm} / \mathrm{dl}$ ) and average post-ET $\mathrm{Hb}$ was $16.2 \mathrm{gm} / \mathrm{dl}$ (range 13.2 - $18.2 \mathrm{gm} / \mathrm{dl}$ ). This resulted in post-ET average indirect serum bilirubin fall by $54.6 \%$ (range $35.2 \%-72.4 \%$ ) and average increase in $\mathrm{Hb}$ by $3.7 \mathrm{gm} / \mathrm{dl}$ (range $2.8-5.8 \mathrm{gm} / \mathrm{dl}$ ). Most common cause of HDN in this study was RhD HDN, which constituted 61 cases (55.5\%) while ABO HDN and other group HDN (non-ABO, non-RhD) were 30 (27.3\%) and 19 (17.3\%) respectively (Table 2).

Post-ET percentage fall of indirect serum bilirubin among different groups was $55.7 \%$ in RhD HDN, $54.1 \%$ in $\mathrm{ABO}$ HDN and $51.8 \%$ in other group HDN (Figure 1) while average increase in $\mathrm{Hb}$ was $3.7 \mathrm{gm} / \mathrm{dl}$ in RhD HDN, $3.8 \mathrm{gm} / \mathrm{dl}$ in $\mathrm{ABO} \mathrm{HDN}$ and $3.6 \mathrm{gm} / \mathrm{dl}$ in other group HDN (Figure 2).

Two newborns of RhD HDN died due to inborn complications, one had neonatal septicemia and other was a preterm, low birth weight baby with respiratory infection. This constituted only 3.2\% case fatality rate among RhD HDN cases and $1.8 \%$ death rate in this study. In the present study septicemia following ET by WBR was not observed.

\section{Discussion}

Present study was conducted to observe the usefulness of whole blood reconstituted (WBR) in exchange transfusion in hemolytic disease of newborn (HDN). Other authors also reported usefulness of WBR over whole blood and component therapy for pump priming in heart surgery in infants $[13,14]$. In ABO-HDN, red cells for exchange transfusion must be of $\mathrm{O}$ group and re-suspended in $\mathrm{AB}$ plasma or $\mathrm{O}$ group whole blood with low Anti $\mathrm{A}$,
Anti B titer [7,9]. Since author(s) have encountered several severe to fatal hemolytic reactions in ABO HDN cases during ET by $\mathrm{O}$ group whole blood, we preferred WBR as a better and safe option. In RhD HDN and other group HDN; O cells are preferred over neonates ABO group cell [15] because of the fact that $\mathrm{ABO}$ blood group antigens are not fully developed in newborns [16] and sub-groups of $\mathrm{A}$ and $\mathrm{B}$ antigens are frequently encountered. We have used $\mathrm{AB}$ plasma for WBR to prevent the transfusion of ABO antibodies, which was not yet developed in neonates [17]. Leuco-reduction helps in preventing most of the febrile reactions, although it is doubtful that it can prevent post transfusion graft verses host disease, as the dose of lymphocytes needed for that is not known [18]. The use of fresh red cells (with in 6 hours of collection) is to ensure the longer survival of transfused RBCs.

In this study, RhD-HDN was the leading cause of HDN with 61 cases (55.5\%) while incidence of ABOHDN and other group HDN (non ABO non RhD) was on an increasing pattern [3], which constituted, 30 cases $(27.3 \%)$ and 19 cases (17.3\%) respectively. Average age of neonate was 4 days and average weight was $2160 \mathrm{gm}$. In previous studies average age and weight were not described. Post-ET fall in hemoglobin was not registered in present study against an average $20 \%$ fall registered in previous studies $[15,19,20]$. In the present study we observed an average increase of $\mathrm{Hb}$ by $3.7 \mathrm{gm} / \mathrm{dl}$ with an

Table 1. Age, weight and volume of WBR in the study. (Cases 110: Exchange transfusions 119).

\begin{tabular}{cccc}
\hline $\begin{array}{c}\text { Cases/Exchange } \\
\text { Transfusions }\end{array}$ & Age in days & Weight in gm & $\begin{array}{c}\text { Volume of WBR } \\
\text { in ml }\end{array}$ \\
\hline Range & 2 to 9 & 1100 to 3100 & 180 to 480 \\
Average & 4 & 2160 & 342 \\
\hline
\end{tabular}

WBR $=$ Whole Blood Reconstituted.

Table 2. 119 Exchange Transfusion in 110 cases: Fall in indirect serum bilirubin and correction of anemia.

\begin{tabular}{|c|c|c|c|c|c|c|c|c|c|}
\hline \multirow{2}{*}{$\begin{array}{l}\text { Cause of } \\
\text { Jaundice }\end{array}$} & \multirow{2}{*}{$\begin{array}{l}\text { No. of Cases } \\
\text { (Percentage) }\end{array}$} & \multirow{2}{*}{$\begin{array}{c}\text { Range of Pre } \\
\text { ET Bilirubin } \\
\text { (Average) } \\
\text { mg/dl }\end{array}$} & \multirow{2}{*}{$\begin{array}{l}\text { Range of Pre } \\
\text { ET Hemoglobin } \\
\text { (Average) gm/dl }\end{array}$} & \multicolumn{2}{|c|}{ ET Required } & \multirow{2}{*}{ Total ET (\%) } & \multirow{2}{*}{$\begin{array}{c}\% \text { Fall of Serum } \\
\text { Bilirubin Range } \\
\text { (Average) }\end{array}$} & \multirow{2}{*}{$\begin{array}{c}\text { Hb Increase } \\
\text { gm/dl } \\
\text { (Average) }\end{array}$} & \multirow{2}{*}{$\begin{array}{c}\text { No. of } \\
\text { Mortality } \\
\text { (Percentage) }\end{array}$} \\
\hline & & & & Once (\%) & Twice (\%) & & & & \\
\hline \multirow{2}{*}{ RhD HDN } & 61 & $20.6-45$ & $10.2-13.9$ & 53 & 08 & 69 & $37.7-70.4$ & $2.8-5.4$ & 02 \\
\hline & (55.56) & (30.48) & (12.21) & (86.8) & (13.2) & (57.98) & (55.66) & (3.70) & (3.2) \\
\hline \multirow{2}{*}{ ABO HDN } & 30 & 16.2 - 29.4 & $10.2-13.9$ & 30 & Nil & 30 & $35.2-65.6$ & $3.0-5.8$ & Nil \\
\hline & (27.28) & (24.16) & (12.65) & (100.00) & $(0.00)$ & (25.22) & (54.12) & (3.83) & $(0.00)$ \\
\hline \multirow{2}{*}{$\begin{array}{l}\text { Other group } \\
\text { HDN }\end{array}$} & 19 & $19.3-40.4$ & $11.4-13.9$ & 18 & 01 & 20 & $40.2-57.6$ & $3.0-4.2$ & Nil \\
\hline & $(17.27)$ & (24.88) & (13.05) & $(94.7)$ & (5.3) & $(16.80)$ & (51.83) & (3.60) & $(0.00)$ \\
\hline \multirow{2}{*}{ Total Cases } & 110 & $16.2-45.0$ & $10.2-13.9$ & 101 & 09 & 119 & $35.2-72.4$ & $2.8-5.8$ & 02 \\
\hline & (100) & (27.94) & (12.46) & (91.82) & (8.18) & (100) & (54.62) & (3.71) & (1.8) \\
\hline
\end{tabular}

ET $=$ Exchange Transfusion. 


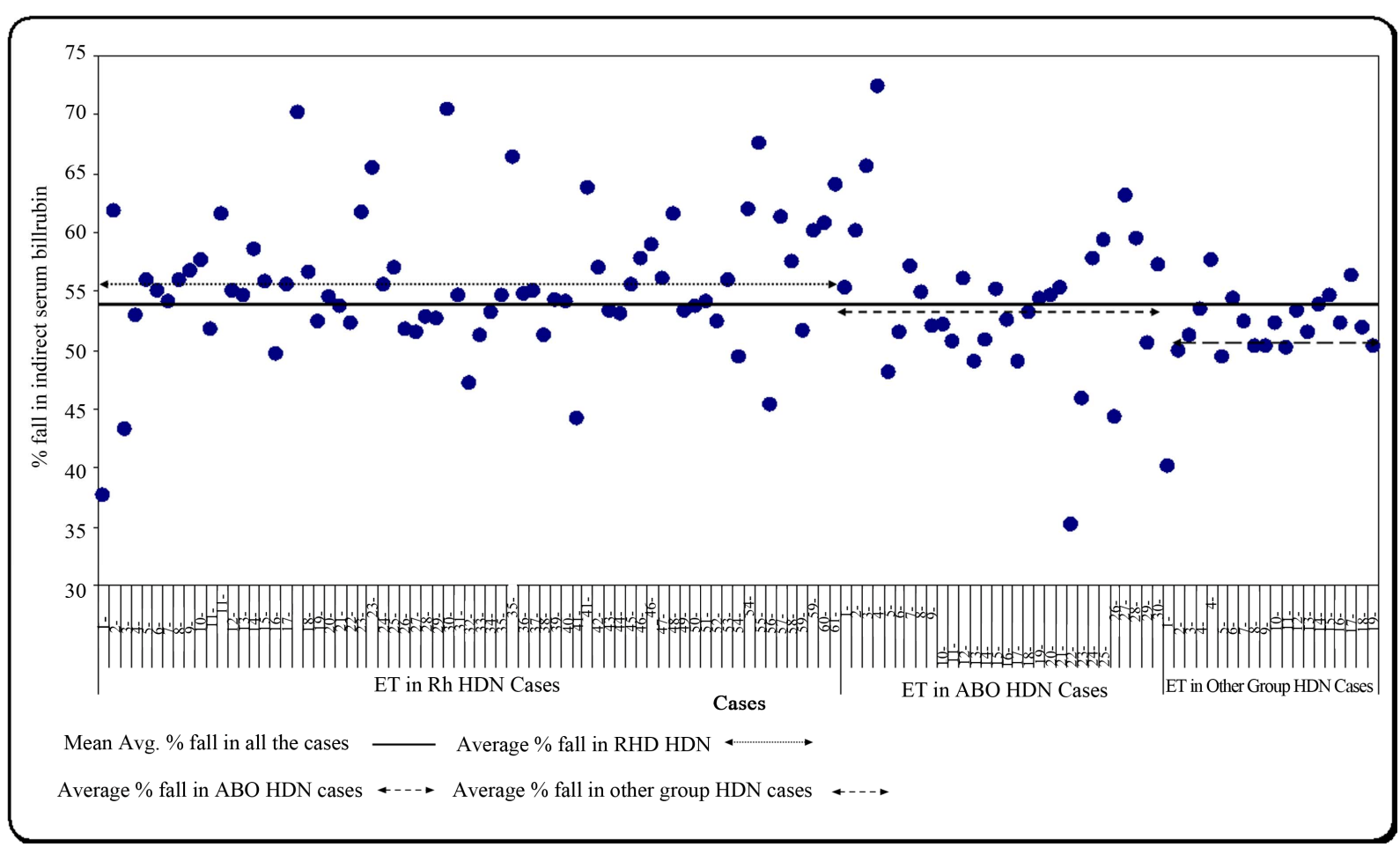

Figure 1. Post ET \% fall in indirect serum bilirubin.

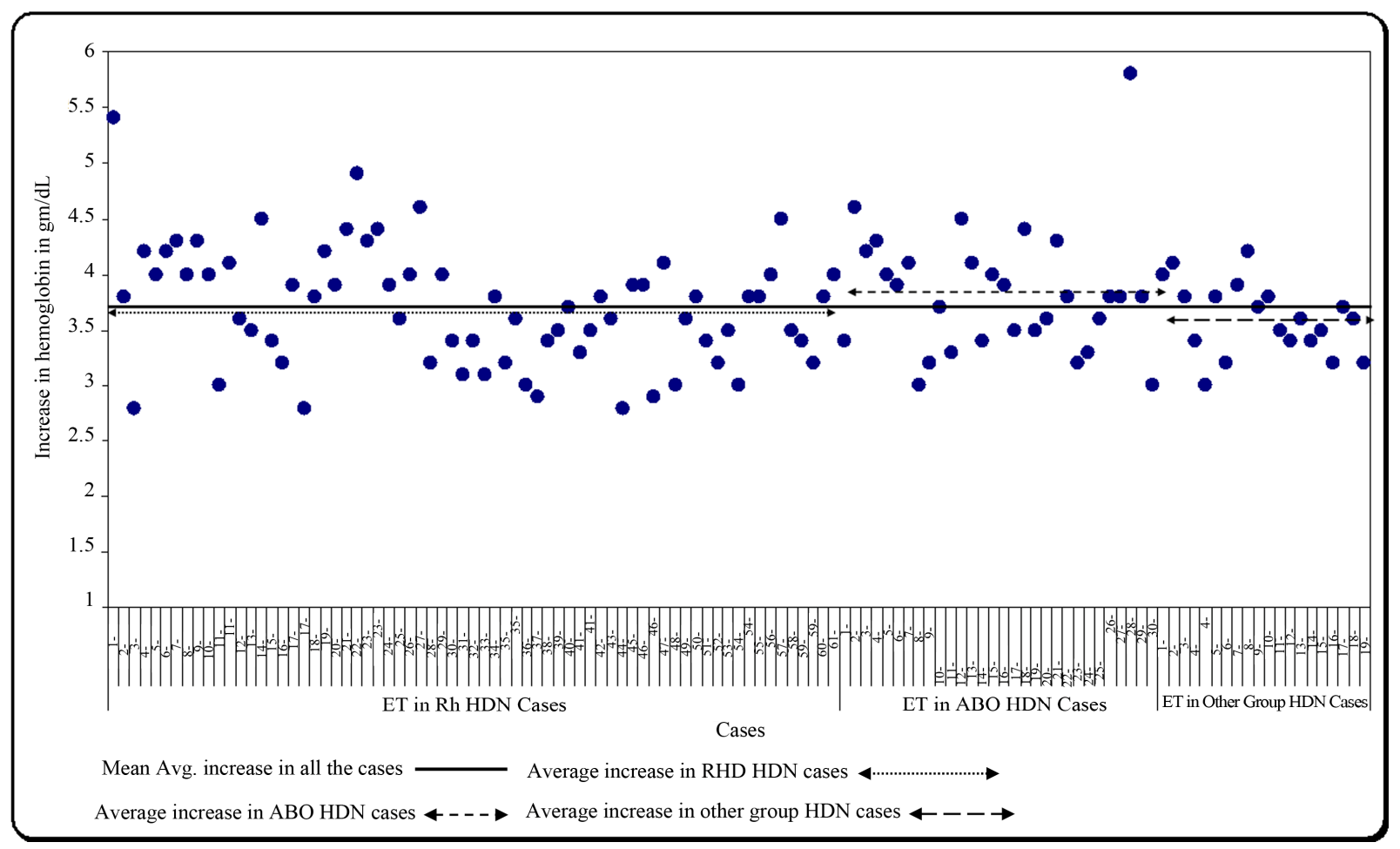

Figure 2. Post ET increase in Hemoglobin in $\mathrm{gm} / \mathrm{dL}$.

average increase of $\mathrm{Hb}$ in $\mathrm{RhD} \mathrm{HDN}$ by $3.7 \mathrm{gm} / \mathrm{dl}$, in ABO HDN by $3.8 \mathrm{gm} / \mathrm{dl}$ and in other group HDN by 3.6 $\mathrm{gm} / \mathrm{dl}$. This was achieved by correcting the technical pitfall in the procedure i.e. adjusting hematocrit of WBR, proper mixing of WBR during ET and monitoring on going process of hemolysis. 
In 61 cases of RhD HDN where pre-ET indirect serum bilirubin was 20.6 - $45 \mathrm{mg} / \mathrm{dl}$, average post-ET indirect serum bilirubin fall was by $55.7 \%$, which was more than comparable studies i.e. $50 \%$ and $51.7 \%$ respectively [15,21]. In 30 cases of ABO-HDN where range of preET indirect serum bilirubin was 16.2 - $29.4 \mathrm{mg} / \mathrm{dl}$, average post-ET indirect serum bilirubin fall was by $54.1 \%$, which was comparable to our previous study in which it was $54.3 \%$ [15].

Third group was of other blood group HDN categorized as non-RhD and non ABO HDN, where other blood group irregular antibodies in the mother's serum were detected by indirect coomb's test (ICT) and corresponding antigen present on neonate RBCs were detected by DCT \& ICT using polyspecific Coomb's serum. Other than RhD and $\mathrm{ABO}$ antibodies, the most common and significant antibodies causing HDN are RhC, Rhc, RhE, Kell I (K) Kell II (k), Js ${ }^{\mathrm{b}}, \mathrm{Fy}^{\mathrm{a}}$ M, S \& V [17,22]. Antibodies usually associated with mild to moderate HDN are $\mathrm{Kp}^{\mathrm{a}}, \mathrm{Kp}^{\mathrm{b}}, \mathrm{LW}, \mathrm{JK}^{\mathrm{a}}, \mathrm{JK}^{\mathrm{b}}, \mathrm{JK} 3, \mathrm{Js}^{\mathrm{a}}$, Ula, (Kel 10) Fy3, etc. [17,22]. Vengelem Tyler V [23] studied and discussed 64 different RBC antibodies specificities reported to cause HDN. Antibodies, which are not associated with $\mathrm{HDN}$, are N, s, PI, Le $\mathrm{Le}^{\mathrm{b}}, \mathrm{Lu}^{\mathrm{a}}$ and $\mathrm{Lu}^{\mathrm{b}}$ [18]. As our centers have no facilities to specify these antibodies, these cases were grouped under non-ABO and non-RhD cases. Total number of such cases was 19 in which pre-ET indirect bilirubin was 19.3 - $40.4 \mathrm{mg} / \mathrm{dl}$. The post-ET average fall in indirect bili- rubin was by $51.8 \%$, which was better than our previous study in which it was $50 \%$ [15].

In all cases mean fall of indirect serum bilirubin was $54.6 \%$, which is better than that documented in literature $[15,21,24]$ in which fall in indirect serum bilirubin was, $50 \%, 51.9 \%$ and $52 \%$ respectively.

ET was carried out on neonates, who were full term healthy/pre-term/ill neonates and few had associated complications. Two deaths of RhD HDN reported in the study comprised of $3.2 \%$ case fatality in this group and $1.8 \%$ death rate in the entire study, which is marginally lower than other study done by Jackson JC. [25] where they have two deaths out of 106 cases (1.88\%).

Author(s) used whole blood reconstituted (WBR) instead of whole blood and preferred $\mathrm{O}$ group cells to neonate's ABO group cells [26]. However, the study conducted in Iran [27] concluded that ET with whole blood reconstituted or fresh whole blood was safe and efficient method for reducing hyperbilirubinemia. The concept of WBR is immunologically valid and can be transfused irrespective of the ABO group of neonate and mother. This concept is easy to understand, simple to follow and desired results are better than whole blood. The immunological complications and risks are very low and HCT, volume and leuco-reduction of WBR can be adjusted as per the requirement of the newborn.

\section{Conclusions}

WBR is immunologically much safer and better than whole blood for purpose of exchange transfusion in HDN because of its superiority in minimizing transfusion reactions and in achieving all the therapeutic effects of exchange transfusion in better way, viz.

1) Removal of indirect serum bilirubin, circulating mother's antibodies and sensitized RBC of neonates from circulation.

2) Better and safe survival of transfused RBC.

3) Percentages fall in indirect serum bilirubin.

4) Post ET correction of anemia.

Results of present study are encouraging as an average fall in indirect serum bilirubin is $54.6 \%$, an average increase of $\mathrm{Hb}$ by $3.7 \mathrm{gm} / \mathrm{dl}$, survival of transfused RBCs is $100 \%$, removal of sensitized RBCs and circulating mother's antibodies is by $85 \%$ - $90 \%$ (double volume exchange transfusion), hence we recommend that exchange transfusion in HDN should be carried out by whole blood reconstituted (WBR), provided that aseptic precautions are maintained during preparation and reconstitution of the blood components.

\section{Acknowledgements}

The author(s) are grateful to Dr. Shaila Sapre, Head of the Institute: Dean G.R. Medical College, Gwalior for her kind cooperation and unstinted support without which this study would have not been possible. The author(s) also acknowledge with deep gratitude the invaluable assistance received from Dr. Navneet Agarwal, B.T.O., Shri Guruji Blood Bank, Gwalior.

\section{REFERENCES}

[1] A. G. Hadley, "Laboratory Assays for Predicting the Severity of Hemolytic Disease of the Fetus and Newborn," Transplant Immunology, Vol. 10, No. 2-3, 2002, pp. 191198. doi:10.1016/S0966-3274(02)00065-5

[2] A. Petrova, R. Mehta, G. Birchwood, B. Ostfeld and T. Hegyi, "Management of Neonatal Hyperbilirubinemia: Pediatricians Practices and Educational Needs," BioMed Central Pediatrics, Vol. 6, 2006, p. 6.

[3] J. M. Bowman, "Historical Overview: Hemolytic Disease of Fetus and Newborn,” In: M. S. Kennedy, S. Wilson and J. G. Kelton, Eds., Perinatal Transfusion Medicine, American Association of Blood Banks, Arlington, 1990, p. 1.

[4] K. J. Peevy and H. J. Wiseman, “ABO Hemolytic Disease of the Newborn: Evaluation of Management and Identification of Racial and Antigenic Factors," Pediatrics, Vol. 61, No. 3, 1978, pp. 475-478.

[5] F. H. Allen, "Choice of Blood for Exchange Transfu- 
sion,” Transfusion, Vol. 6, No. 2, 1996, pp. 101-103. doi:10.1111/j.1537-2995.1966.tb04705.x

[6] S. D. Roseff, N. L. C. Luban and C. S. Manno, “Guidelines for Assessing Appropriateness of Pediatric Transfusion,” Transfusion, Vol. 42, No. 11, 2002, pp. 1398-1413. doi:10.1046/j.1537-2995.2002.00208.X

[7] B. G. Solheim and M. Gronn, "Hemolytic Disease of Newborn,” In: T. L. Simon, Ed., Rossi Principles of Transfusion Medicine, 3rd Edition, Lippincott Williams \& Wilkens, Philadelphia, 2002, p. 442.

[8] R. Jayashree and N. I. C. Luban, "Transfusion Practices,” In: P. de Alarcón, E. Werner and J. L. Naiman, Eds., Neonatal Hematology, Cambridge University Press, Cambridge, 2005, p. 354.

[9] R. Jayashree, "Hemolytic Disease of the Newborn,” In: R. Strauss, C. Hillyer and L. C. Naomi, Eds., Hand Book of Pediatric Transfusion Medicine, Vol. 18, Academic Press, Waltham, 2004, pp. 203-206.

[10] Subcommittee on Hyperbilirubinemia: American Academy of Pediatrics, "Management of Hyperbilirubinemia in the Newborn Infant 35 or More Weeks of Gestation," Pediatrics, Vol. 114, No. 1, 2004, pp. 297-316.

[11] J. R. Martin, “A Double Catheter Technique for Exchange Transfusion in the Newborn Infant," The New Zealand Medical Journal, Vol. 77, No. 490, 1973, pp. 167-169.

[12] C. R Martin and J. P. Cloherty, "Neonatal Hyperbilibubinemia," In: J. P. Cloherty and A. R. Stark, Eds., Manual of Neonatal Care, 5th Edition, Lippincott Williams \& Wilkins, Philadelphia, 2004, pp. 185-221.

[13] S. S. Mau and B. P. Giroir, "Fresh Blood versus Reconstituted Blood for Pump Priming in Heart Surgery in Infants," New England Journal of Medicine, Vol. 351, 2004, pp. 1635-1644. doi:10.1056/NEJMoa041065

[14] C. Gruenwald, B. W. McCrindle and C.-L. Lynn, "Reconstituted Fresh Whole Blood Improves Clinical Outcomes Compared to Stored Component Therapy for Neonates Undergoing Cardio-Pulmonary Bypass for Cardiac Surgery,” Circulation, Vol. 116, 2007, pp. 412-413.

[15] D. C. Sharma, S. Rai, A. Mehra, M. Kaur, S. Sao, A. Gaur and R. Sapra, "Study of 25 Cases of Exchange Transfusion by Reconstituted Blood in HDN," Asian Journal of Transfusion Science, Vol. 1, No. 2, 2007, pp. 56-58. doi:10.4103/0973-6247.33448

[16] T. Kemp, "Üben den Emptindlichkeisgrad der Blutkörperchen Gegenüber Isohämagghrtininen im Fötalleben und im Kindesalter beim Menschen,” Acta Pathologica
Microbiologica ET Immunologica Scandinavica, Vol. 7, No. 2, 1930, p. 146.

[17] M. S. Kennedy and A. Waheed, "Hemolytic Disease of Newborn and Fetus,” In: D. M. Harmening, Ed., Modern Blood Banking and Transfusion Practices, 3rd Edition, Jaypee Brothers Medical Publishers LTD, New Delhi, Vol. 20, 1998, pp. 393-396.

[18] M. S. Kennedy and J. Carmen, “Transfusion Therapy,” In: D. M. Harmening, Ed., Modern Blood Banking and Transfusion Practices, 3rd Edition, Jaypee Brothers Medical Publishers LTD, New Delhi, Vol. 16, 1998, pp. 319-324.

[19] W. J. Jablonski, "Risks Associated with Exchange Transfusion," New England Journal of Medicine, Vol. 266, 1962, pp. 155-160. doi:10.1056/NEJM196201252660401

[20] P. B. Simmons, L. E. Harris and A. J. Bianco, “Complications Following Exchange Transfusion. Report of Two Cases of Septic Arthritis and Osteomyelitis,” Mayo Clinic Proceedings, Vol. 48, No. 3, 1973, pp. 190-193.

[21] G. B. Odell, P. L. Poland and E. M. Ostrea, "Neonatal Hyperbilirubinemia,” In: M. H. Klaus and A. A. Fanaroff, Eds., Care of the High-Risk Neonate, Philadelphia, London,1973, pp. 183-204.

[22] P. E. Waldron and W. J. Cashore, "Hemolytic Disease of Fetus and Newborn,” In: P. A. de Alareou and E. J. Werner, Eds., Neonatal Hematology, Vol. 6, Cambridge University Press, Cambridge, 2005, p. 92.

[23] V. Vengelen-Tyler, “The Serological Investigation of Hemolytic Disease of the Newborn Caused by Antibodies Other than Anti-D,” In: G. Garratty, Ed., Hemolytic Disease of Newborn, American Association of Blood Bank, Arlington, 1984, p. 145.

[24] R. H. Merchant and S. H. Abhyankar, "Exchange Transfusions in Newborns: An Analysis of 100 Cases," Indian Pediatrics, Vol. 22, No. 5, 1985, pp. 349-353.

[25] J. C. Jackson, “Adverse Event with Exchange Transfusion in Healthy and Ill Newborns,” Pediatrics, Vol. 99, No. 5, 1977, p. e7. doi:10.1542/peds.99.5.e7

[26] Transfusion Guidelines for Neonates and Older Children, "British Committee for Standards in Hematology: Blood Transfusion Task Force,” British Journal Hematology, Vol. 124, No. 4, 2004, pp. 433-453.

[27] M. M. Gharehbaghi and S. S. Hosseinpour, "Exchange Transfusion in Neonatal Hyperbilirubinaemia: A Comparison between Citrated Whole Blood and Reconstituted Blood,” Singapore Medical Journal, Vol. 51, No. 8, 2010, pp. 641-644. 